\title{
PENGARUH GAYA HIDUP MEROKOK TERHADAP \\ KEJADIAN INFARK MIOKARD AKUT (IMA) DI RSU BETHESDA TOMOHON
}

\author{
${ }^{1}$ Geiby F. Kalalo \\ ${ }^{2}$ Jandry Pangemanan \\ ${ }^{3}$ A. Lucia Panda
}

\author{
Bagian Kardiologi dan Kedokteran Vaskular \\ Fakultas Kedokteran Universitas Sam Ratulangi Manado \\ Email: geibykalalo09152@yahoo.com
}

\begin{abstract}
Abstrak : Kebiasaan dan rutinitas yang merugikan memiliki kekuatan untuk merusak kesehatan seseorang seperti kebiasaan merokok yang merupakan contoh kebiasaan untuk memudahkan seseorang terkena penyakit kardiovaskuler. ${ }^{2}$ Sekitar 1,5 juta kasus infark miokard terjadi setiap tahun di Amerika Serikat dengan tingkat kejadian tahunan adalah sekitar 600 kasus per 100.000 orang. $^{3}$ Data di RS Pusat Jantung Nasional Harapan Kita menunjukkan IMA pada usia muda pada tahun 2008 adalah 108 kasus dari total 1065 kasus IMA. ${ }^{4}$ Menurut prediksi WHO, pada tahun 2020 penyakit jantung dan stroke yang saat ini menjadi penyebab kematian utama di negara maju nantinya menjadi penyebab kematian pertama di dunia. $^{2}$ Tujuan : Tujuan penelitian ini yaitu untuk mengidentifikasi pengaruh gaya hidup merokok terhadap kejadian infark miokard akut di RSU Bethesda Tomohon. Metode : Metode penelitian yang dilakukan bersifat case control retrospektif. Hasil : Karakteristik responden berdasarkan umur didapatkan bahwa pada kelompok kasus sebagian responden dengan gaya hidup merokok berat pada umur $\geq 50$ tahun sebesar $56 \%$, sedangkan pada kelompok kasus sebagian responden dengan gaya hidup merokok berat pada umur 30-50 tahun sebesar 36\%. Untuk karakteristik berdasarkan lamanya merokok didapatkan bahwa sebagian responden yang lamanya merokok $\geq 10$ tahun memiliki persentase lebih besar dibandingkan dengan lamanya merokok 5-10 tahun dimana pada kalompok kasus sebesar 76\% dan kelompok kontrol sebesar $84 \%$. Gaya hidup merokok berat yang tidak terjadi IMA dan yang terjadi IMA memiliki persentase responden lebih besar dibandingkan dengan gaya hidup merokok sedang, dimana gaya hidup merokok berat yang tidak terjadi IMA sebesar 28\% sebanyak 14 responden dan yang terjadi IMA sebesar 30\% sebanyak 15 responden. Kesimpulan :. Kejadian IMA pada kelompok kasus dan kelompok kontrol sebagian besar terjadi pada gaya hidup merokok berat. Pengaruh gaya hidup merokok berat dengan kejadian IMA, memiliki signifikan pengaruh yang sangat kuat.
\end{abstract}

Kata Kunci : Infark Miokard Akut, Gaya Hidup Merokok 
Abstract : Habits and routinity that gives bad effects have the potential to ruin a persons health, just like the smoking habit as the example that make someone has cardiovascular disease. There's about 1,5 million myocardial infarction happened every year in USA with annual incidence of 600 cases for each 100.000 person. The database of Harapan Kita Heart Center shows that IMA cases of the young people on 2008 is 108 cases from the total 1065 IMA cases. According to who prediction on 2020, heart disease and stroke which was the main cause of deaths on developed countries will be the world's main cause of deaths too. Objective: The purpose of this research is to identify the influence of smoking habits to IMA disease at Bethesda Hospital Tomohon.

Methods: The methods on this research is case control retrospective.

Result: The characteristic of the respondents according to their age, most of them has severe smoking habits at the age of $\geq 50$, the percentage is $56 \%$. While the others with severe smoking habits at the age of $30-50$ is at $36 \%$. For the characteristic according to how long they've been smoking, $\geq 10$ years has more percentage than those who have been smoking for 5-10 years, where on the case group at $76 \%$ and the control group at $84 \%$. Severe smoking habits who didn't had IMA and those who had IMA, had higher respondents percentage than those with medium smoking habits, with those with severe smoking habits and don't had IMA is 14 respondents at $28 \%$ and those who had IMA is 15 respondents at $30 \%$. Conclusion: IMA cases on case group and control group mostly happened on those with severe smoking habits. Smoking habits has a very strong and significant influence to IMA cases.

Key Words: Acute Myocardial Infarction, Smoking Habits

\section{PENDAHULUAN}

Penurunan tingkat penyakit jantung iskemik dan infark miokard yang terkait dengan kematian, dalam hubungannya dengan percepatan pembangunan ekonomi dan gaya hidup perubahan yang mempromosikan aterosklerosis, diharapkan meningkat tajam di negara-negara berkembang, terutama negara-negara seperti di Eropa Timur, Asia, dan sebagian Amerika Latin. ${ }^{1}$ Kebiasaan merokok, mengkonsumsi alkohol, diet tinggi lemak jenuh, merupakan contoh kebiasaan yang memudahkan seseorang terkena penyakit kardiovaskuler. $^{2}$

Sekitar 1,5 juta kasus infark miokard terjadi setiap tahun di Amerika Serikat, dengan tingkat kejadian tahunan adalah sekitar 600 kasus per 100.000 orang. Meskipun penurunan yang mengesankan di usia yang disesuaikan dengan angka kematian yang disebabkan infark miokard akut sejak pertengahan 1970-an, jumlah infark miokard yang berhubungan dengan kematian di Amerika Serikat belum menurun, hal ini sebagian mungkin merupakan hasil dari pertumbuhan penduduk. ${ }^{1}$ Data di Rumah Sakit Pusat Jantung Nasional Harapan Kita menunjukkan IMA pada usia muda pada tahun 2008 adalah 108 kasus dari total 1065 kasus IMA, atau dengan kata lain sebesar 10,1\%. ${ }^{3}$

Infark miokard akut merupakan salah satu diagnosis rawat inap tersering di negara maju. Laju mortalitas awal (30 hari) pada IMA adalah 30\% dengan lebih dari separuh kematian terjadi sebelum pasien mencapai rumah sakit. Walaupun laju mortalitas menurun sebesar 30\% dalam 2 dekade terakhir, sekitar 1 diantara 25 pasien 
yang tetap hidup pada perawatan awal, meninggal dalam tahun pertama setelah IMA. ${ }^{4}$ Menurut prediksi WHO, pada tahun 2020 penyakit jantung dan stroke yang saat ini menjadi penyebab kematian utama di negara maju nantinya menjadi penyebab kematian pertama di dunia. ${ }^{2}$

Tingginya angka kejadian infark miokard akut di Sulawesi Utara, khususnya di kota Tomohon sehingga mendorong penulis untuk melakukan penelitian mengenai pengaruh gaya hidup merokok dengan kejadian IMA di RSU Bethesda Tomohon.

\section{METODE PENELITIAN}

Penelitian yang dilakukan bersifat case control retrospektif dimana kelompok kasus merupakan pasien infark miokard yang memiliki perilaku kebiasaan merokok di RSU Bethesda Tomohon, sedangkan untuk kelompok kontrol merupakan klien yang tidak menderita infark miokard tetapi memiliki perilaku kebiasaan merokok di Mahawu Badminton Club.

Penelitian ini dilakukan di kota Tomohon pada bulan oktober 2012 - november 2012. Adapun populasi dalam penelitian ini yaitu pasien infark miokard akut di RSU Bethesda Tomohon dengan cara pemilihan sampelnya yaitu non-probability sampling jenis consecutive sampling.

Kriteria inklusi penelitian ini yaitu : pria usia 30-65 tahun, pasien infark miokard, dan mempunyai gaya hidup merokok, sedangkan untuk kriteria eksklusinya yaitu dimana responden meninggal dunia.

Variabel yang digunakan yaitu variabel bebas (independent) adalah gaya hidup merokok, sedangkan variabel tergantung (dependent) adalah infark miokard akut.

Instrumen penelitian meliputi : kuesioner, wawancara, Menguji validitas kuesioner dengan jenis korelasi pearson dan reabilitasnya dengan menggunakan metode alpha cronbach secara otomatis di lakukan oleh software SPSS.

Cara kerja untuk penelitian ini yaitu yang pertama mengumpulkan semua pasien dengan IMA kemudian memilih sampel pasien infark miokard dengan cara nonprobability sampling jenis consecutive sampling yang telah memenuhi kriteria inklusi yang telah ditetapkan, yang kedua mengolah data berdasarkan variabel penelitian dan disajikan dengan cara menyusunnya dalam bentuk tabel, grafik, dan persentase, kemudian melakukan konsultasi dengan dosen pembimbing, penyusunan dan pengetikan naskah akhir dan yang terakhir menelaah kembali naskah.

\section{HASIL PENELITIAN}

Hasil penelitian ini akan membahas mengenai gambaran secara umum lokasi penelitian, karakteristik demografi responden, variabel yang diukur berkaitan dengan pengaruh gaya hidup merokok terhadap kejadian infark miokard akut. Data-data tersebut diperoleh dengan menyebarkan kuesioner pada responden yang merokok, responden yang diperoleh berjumlah 50 orang yaitu 25 orang pada kelompok kasus dan 25 orang pada kelompok kontrol.

Dari pengumpulan data yang dilaksanakan tanggal 27 November sampai dengan 15 Desember 2012 di RSU Bethesda Tomohon dan Mahawu Badminton Club Tomohon, peneliti mendapatkan data-data sebagai berikut. 
Tabel 1. Karakteristik Responden Berdasarkan Umur

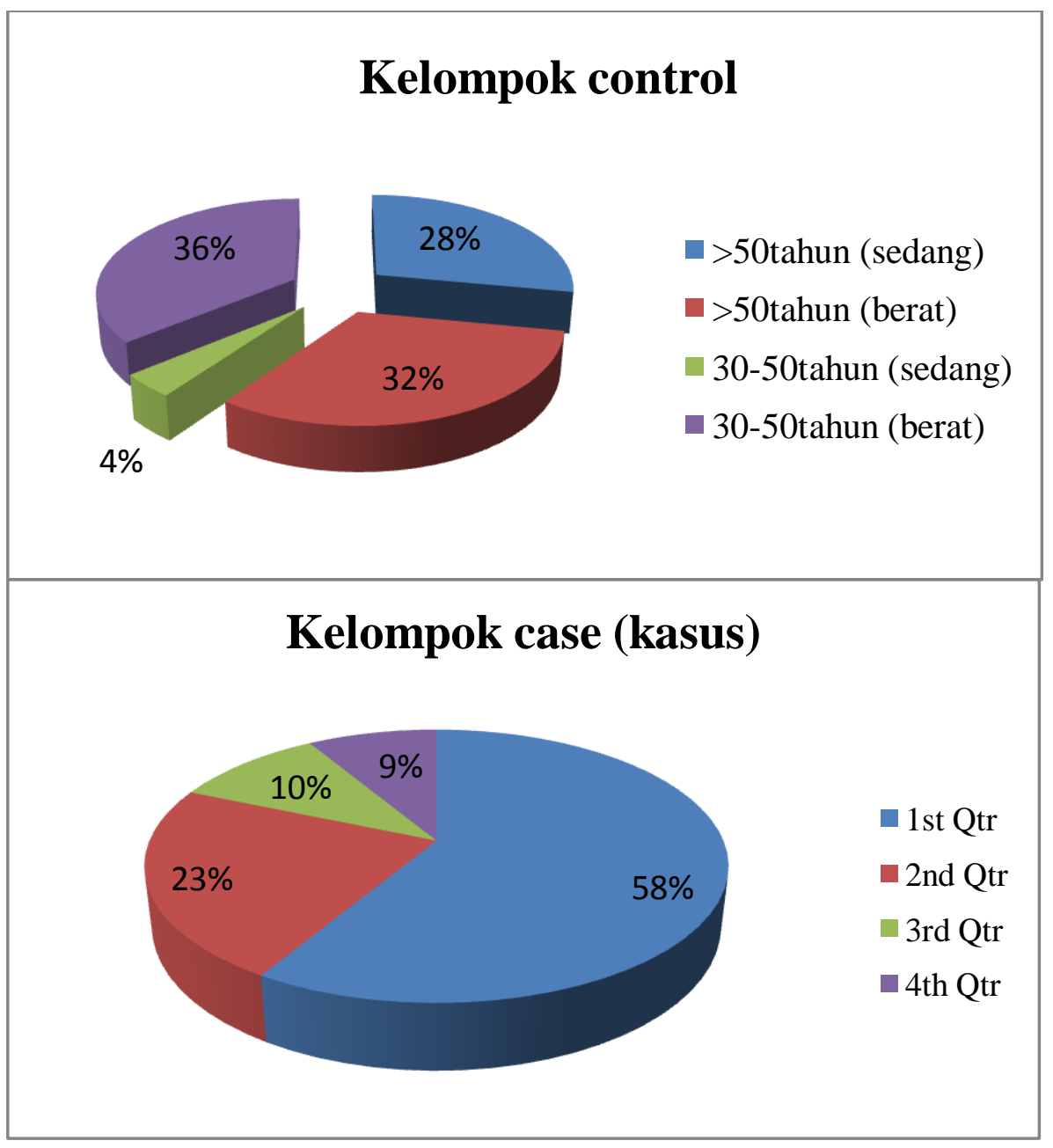


Tabel 2. Karakteristik berdasarkan lamanya merokok

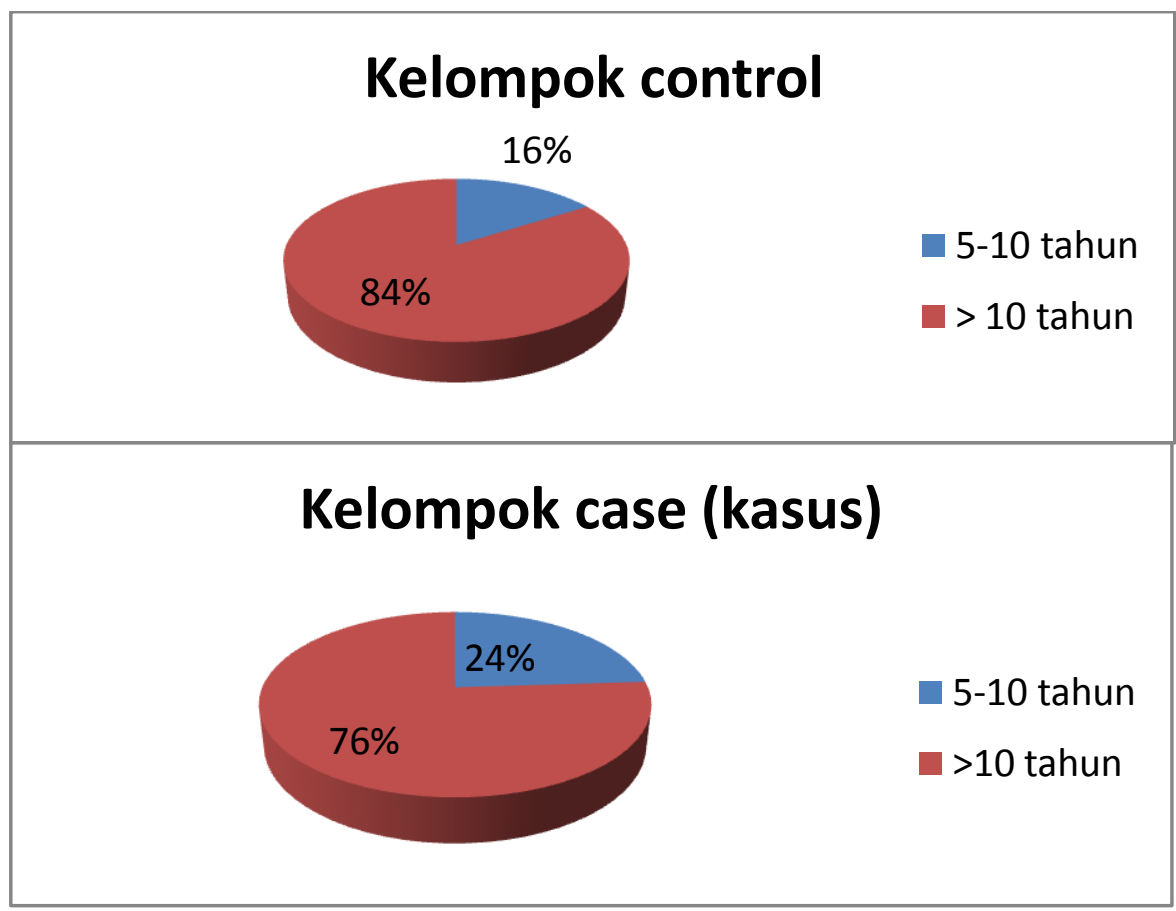

Tabel 3. Analisis univariat berdasarkan gaya hidup merokok

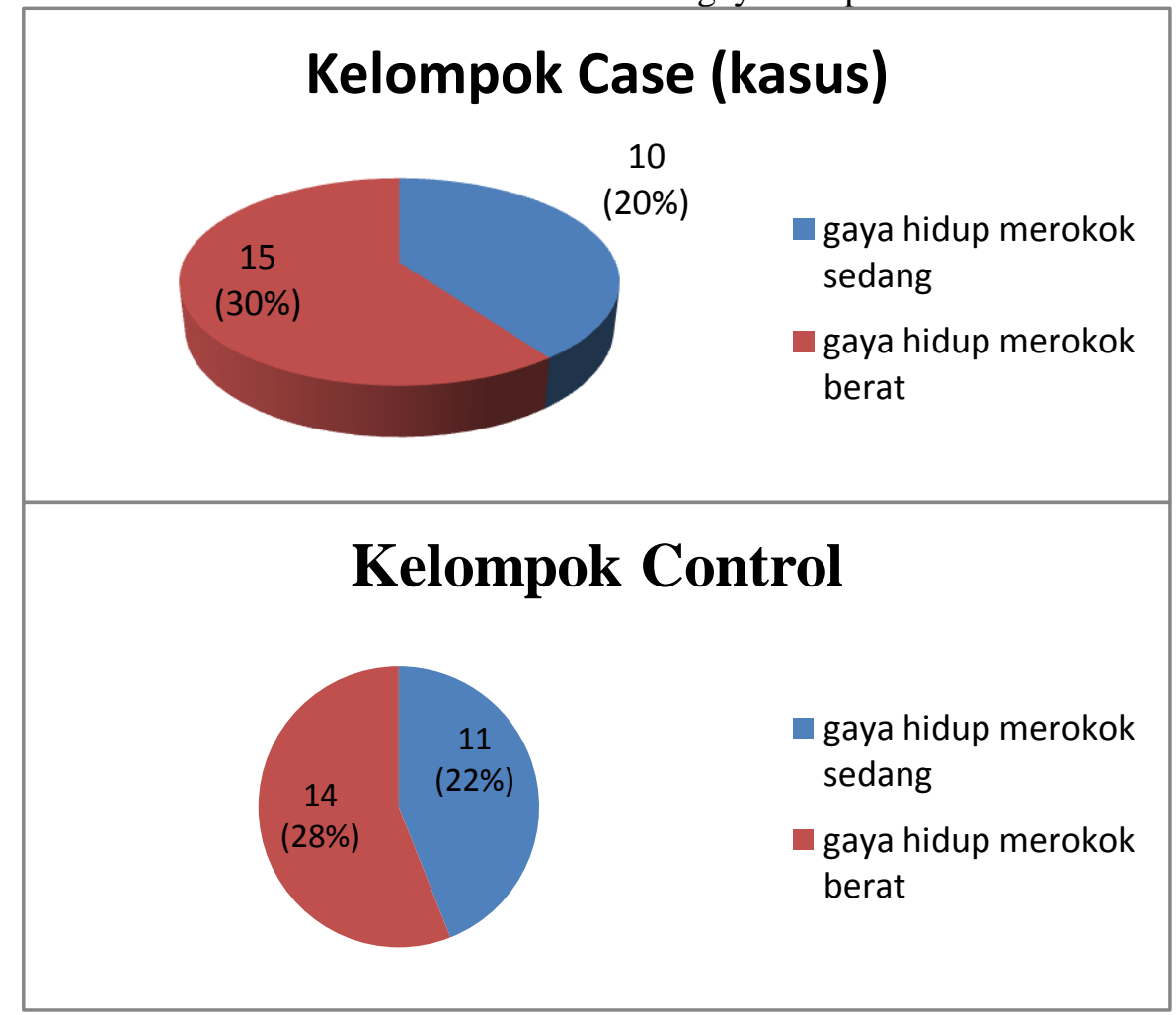


Tabel 4. Analisis Bivariat Pengaruh Gaya Hidup Merokok terhadap IMA di RSU Bethesda Tomohon Nov - Des 2012

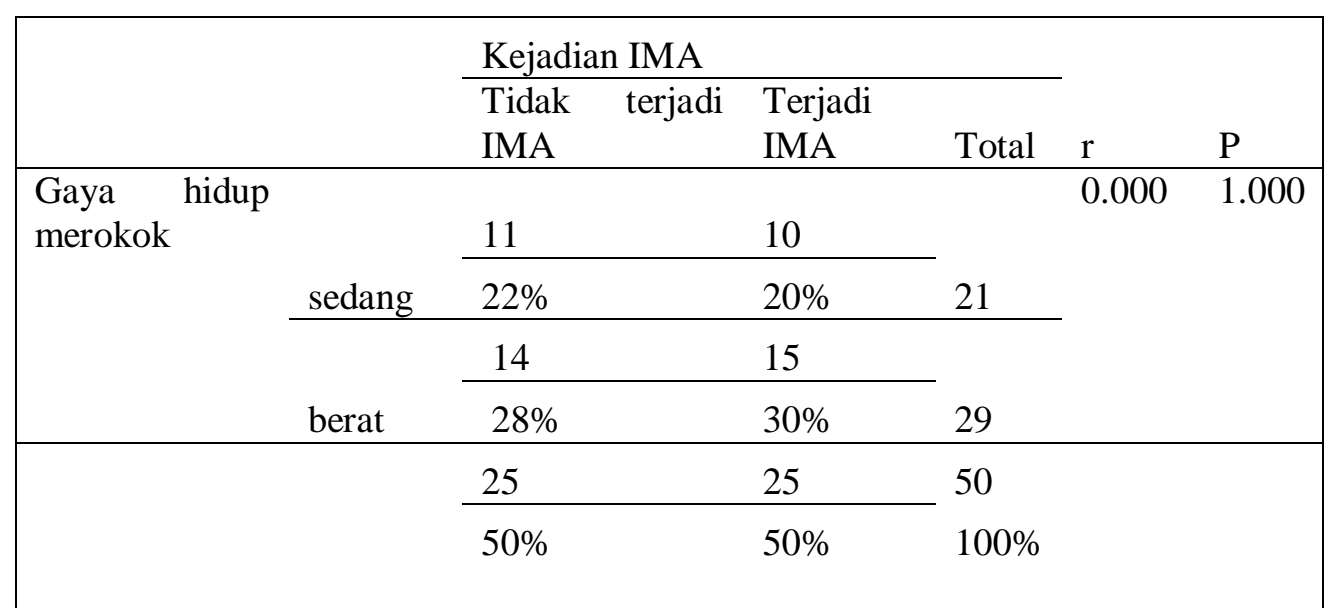

Uji statistik menggunakan analisis chi square didapatkan hasilnya yaitu 0,000 dimana $\alpha<0,05$ dan significancy $p=1.000$ yang artinya hubungan sangat kuat, antara gaya hidup merokok dengan kejadian infark miokard akut.

\section{PEMBAHASAN}

Kebiasaan dan rutinitas yang merugikan memiliki kekuatan untuk merusak kesehatan seseorang seperti kebiasaan merokok yang merupakan contoh kebiasaan untuk memudahkan seseorang terkena penyakit kardiovaskuler. Setelah dilakukan analisa data dan menguji hasil penelitian dengan menggunakan Uji statistik Chi Square Test diperoleh hasil yang memerlukan pembahasan tentang pengaruh gaya hidup merokok terhadap kejadian infark miokard akut. Dari 34 kasus infark miokard pada pria yang terdaftar di ruang ICU RSU Bethesda Tomohon selama tahun 2011-2012, terdapat 25 kasus atau pasien dengan infark miokard akut pada pria yang masih hidup dan dijadikan sebagai responden.

Berdasarkan hasil analisis yang didapat, gaya hidup merokok sedang pada kelompok yang tidak terjadi IMA sebesar 22\% dengan jumlah 11 responden dimana mereka mampu menghabiskan 11-12 batang rokok dengan selang waktu 31-60 menit setelah bangun pagi. Sedangkan untuk gaya hidup merokok berat sebesar 28\% dengan jumlah 14 responden dimana mereka mampu menghabiskan rokok 21-31 batang per hari atau lebih, dan selang waktu sejak bangun pagi berkisar antara 6-30 menit. ${ }^{5}$ Dengan begitu gaya hidup merokok berat mempunyai persentase responden lebih besar di bandingkan dengan gaya hidup merokok sedang.

Pada penelitian ini semua responden kelompok kontrol tidak terjadi IMA, padahal sebagian responden dengan gaya hidup merokok berat. Hal ini berkaitan dengan gaya hidup dari kelompok kontrol yang secara teratur melakukan kegiatan olahraga bulutangkis seminggu 3 kali, dimana setiap pemain secara bergantian dapat bermain ratarata 2 set permainan, dengan jangka waktu 30-60 menit/permainan dilakukan berselang waktu.

Berolahraga dapat memperkuat otot dalam tubuh yang bekeja paling keras yaitu jantung. Olahraga teratur memacu tubuh mencapai detak jantung optimal — 60 sampai 70 persen dari detak jantung maksimal-dapat membuat jantung berdetak secara lebih efisien, memperkuat pembuluh arteri dan melancarkan sirkualsi. Penelitian menunjukkan bahwa aktivitas fisik yang dilakukan secara teratur mampu mengurangi resiko terkena penyakit jantung sebanyak 50 persen dan menyebabkan perubahan kimia pada darah yang dapat membantu melindungi dari serangan jantung. ${ }^{6}$ 
Gaya hidup merokok sedang pada kelompok yang terjadi IMA sebesar 20\% dengan jumlah 10 responden, sedangkan gaya hidup merokok berat sebesar 30\% dengan jumlah 15 responden. Dengan melihat persentase antara perokok sedang dan berat pada kelompok yang terjadi IMA, dapat disimpulkan bahwa pada penelitian ini gaya hidup merokok berat dengan persentase responden yang banyak, memiliki resiko lebih besar untuk terkena infark miokard akut.

Dari hasil penelitian lewat pengisian kuesioner dan wawancara, di dapatkan juga ada beberapa responden dengan gaya hidup merokok sedang tetapi sudah terjadi IMA, hal ini disebabkan karena ada faktor resiko lain seperti hipertensi atau kolesterol. Hipertensi terjadi karena menyempitnya pembuluh darah yang diakibatkan oleh mengendapnya kalsium (darah dalam kondisi terlalu basa) dan kolesterol di dinding pembuluh darah. Ditambah dengan konsentrasi darah yang kental karena tingginya natrium berakibat aliran darah kurang lancar sehingga menghambat suplai makanan dan oksigen ke jaringan dan sel tubuh. Kondisi tersebut memacu jantung untuk bergerak dan bekerja lebih keras, akibatnya tekanan darah menjadi tinggi dan dalam jangka waktu tertentu bisa menyebabkan serangan jantung. ${ }^{7}$ Dulu kolesterol dianggap sebagai satu-satunya fakor utama, namun dari beberapa penelitian menunjukkan, kira-kira $50 \%$ serangan jantung di Amerika terjadi pada populasi yang kolesterolnya dalam batas normal. ${ }^{8}$

Menurut penelitian Fonarow G, dari school of medicine at the university of california, Los Angeles, seseorang dapat mengalami serangan jantung tanpa faktor resiko lain jika seseorang tersebut merokok, ${ }^{9}$ atau bila Anda hanya seorang perokok, atau mempunyai salah satu faktor resiko seperti hipertensi atau kolesterol tinggi, Anda mempunyai risiko untuk mengalami serangan jantung 2 kali lebih besar dari populasi yang normal. Dengan kata lain, bila Anda merokok, Anda mempunyai risiko mengalami serangan jantung 2 kali lebih besar dari yang tidak merokok. Bila Anda mempunyai 2 faktor risiko tersebut, risiko Anda meningkat 4 kali, dan bila Anda mempunyai 3 faktor risiko (merokok, hipertensi, kolesterol), maka risiko Anda untuk mengalami serangan jantung juga meningkat 8 kali. $^{8}$

Berdasarkan karakteristik responden untuk penggolongan umur ditemukan bahwa pada kelompok kasus sebagian responden dengan gaya hidup merokok berat sebesar $56 \%$ terjadi pada umur $\geq 50$ tahun yang berjumlah 14 responden. Sedangkan untuk kelompok kontrol sebagian responden dengan gaya hidup merokok berat sebesar $36 \%$ terjadi pada umur 30-50 tahun yang berjumlah 9 responden. Hal ini sejalan dengan penelitian Fonarow G, mengatakan bahwa pasien laki-laki perokok rata-rata dirawat dirumah sakit karena serangan jantung pada usia 55 tahun. ${ }^{9}$ Dengan kata lain penelitian ini didapatkan bahwa sebagian responden dengan gaya hidup merokok berat terjadi baik pada umur 30-50 tahun maupun $\geq 50$ tahun.

Berdasarkan karakteristik lamanya merokok dan dihubungkan dengan gaya hidup merokok, didapatkan bahwa pada kelompok kasus sebagian responden yang lamanya merokok $\geq 10$ tahun sebesar $76 \%$ terjadi pada gaya hidup merokok berat sebesar $52 \%$ berjumlah 13 responden. Sedangkan pada kelompok kontrol didapatkan juga hal yang sama dimana sebagian responden yang lamanya merokok $\geq 10$ tahun terjadi pada gaya hidup merokok berat, akan tetapi dengan persentase yang lebih tinggi yaitu lamanya merokok $\geq 10$ tahun sebesar $84 \%$ dan gaya hidup merokok berat pada lamanya merokok $\geq 10$ tahun sebesar $60 \%$ berjumlah 15 responden. Hal ini juga sejalan dengan penelitian dari G Fonarow, didapatkan bahwa pasien laki-laki yang tidak merokok di rawat di rumah sakit karena serangan jantung rata-rata pada usia 65 tahun, sedangkan laki-laki perokok rata-rata dirawat dirumah sakit pada usia 55 tahun. Dengan begitu seorang perokok 10 tahun lebih cepat terkena serangan jantung daripada bukan perokok, dan seorang perokok dengan lamanya merokok $>10$ tahun lebih beresiko terkena IMA. 


\section{SIMPULAN}

Pengaruh gaya hidup merokok terhadap kejadian infark miokard akut memiliki signifikan pengaruh yang sangat kuat.

\section{DAFTAR PUSTAKA}

1. Yang EH, Zafari AM, et al. Myocardial Infarction [internet]. Available from: http://emedicine.medscape.com/article/155919-overview.html. Accessed Oktober 24, 2012.

2. Cahyono JB. Gaya Hidup dan Penyakit Modern. Yogyakarta: Kanisius; 2008.

3. Rumah Sakit Pusat Jantung Nasional Harapan Kita. Data rekam medis. 2009.

4. Tambajong J. Patofisiologi - Konsep Klinis Proses-proses Penyakit. Edisi ke 4. Jakarta: EGC; 1995

5. Kalalo P. Perilaku Pelajar SMA Kr. Eben Haezer Terhadap Merokok [skripsi]. Universitas Sam Ratulangi Manado, Tomohon; 2010

6. Olahraga untuk pencegahan dan penyembuhan penyakit [internet]. From: http://www.deherba.com/faktor-faktor-utama-terkena-resiko-penyakit-jantung.html. Akses Januari 15, 2013.

7. Krisnamurti D. Dari Hipertensi Hingga Serangan Jantung [internet]. From: http://www.inilah.com/read/detail/1825073/dari-hipertensi-hingga-seranganjantung/. Akses Januari 15, 2013.

8. Rusad I, Joseph BP, Barry AF. Serangan Jantung [internet]. From: http://kesehatan.kompasiana.com/medis/2011/02/06/adjie-massaid-alm-mengalami serangan-jantung. Akses Januari 15, 2013.

9. Perokok lebih cepat 10 tahun terkena serangan jantung [internet]. From: http://infokomunikacom/2011/10/perokok-lebih-cepat-10-tahun-terkena.html. Akses Januari 15, 2013. 